Wojciech KRÓWCZYŃSKI, M.A., doctoral studies in economics

Faculty of Management and Social Communication at Jagiellonian University in Krakow

e-mail: wojciech.krowczynski@doctoral.uj.edu.pl

DOI: $10.15290 /$ oes.2018.01.91.06

\title{
THE INFLUENCE OF THE REGULATION OF EUROPEAN PARLIAMENT AND COUNCIL OF THE EUROPEAN UNION (GDPR) ON THE LEVEL OF TRANSACTIONAL COSTS OF MANAGING MEDICAL DATA IN MEDICAL ENTITIES
}

\begin{abstract}
Summary
The aim of the paper is to present the impact of GDPR regulation on the level of transactional costs in the management of medical data in medical entities. The management of medical data has been presented as a series of activities of transactional nature. Futhermore, the impact of institutional solutions of the GDPR on the specificity of assets, the frequency and uncertainty of transactions included in the management of medical data was considered. As the result of the analysis, the following conclusions were drawn: 1 . The new regulations defined in the regulation of the GDPR will significantly increase the transactional costs of adaptation measures. 2. The implemented changes will result in the greater specificity of both the assets and the frequency of transactions. 3. The effect of introducing changes will be a partial reduction of the uncertainty accompanying the transactions. The rights and obligations of the parties in the process of managing medical data will become more transparent.
\end{abstract}

Key words: medical entities, medical data, transactional costs, institutions, economics of transactional costs

\section{Introduction}

The paper includes the analysis of the influence of European Parliament and the Council of the European Union $(\mathrm{GDPR})^{1}$ regulation on the management of medical data $^{2}$ in medical entities ${ }^{3}$ from the perspective of the incurred transactional costs. The regulations considerably expand the range of authorizations of persons whose data is processed. In particular, the changes in this sphere regard the medical data

1 Regulation (EU) 2016/679 of the European Parliament and of the Council of 27 April 2016 on the protection of natural persons with regard to the processing of personal data and on the free movement of such data, and repealing Directive 95/46/EC (General Data Protection Regulation) (Eur-Lex 119 of 04.05.2016, p. 1).

2 Data regarding the state of health, genetic and biometrical data in this publication is defined as medical data.

3 The elaboration includes the term medical entities in accordance with the act of medical activity of 15 April 2011 (uniform text: Journal of Acts 2018 item 160 with further alterations). 
that is indispensable for carrying out a medical activity. Owing to the new requirements of GDPR, medical entities must implement new modifications in terms of the management of medical data. These activities are accompanied by certain transactional costs. The aim of the paper is to show the way the transactional costs incurred during the implementation of modifications are changing as the result of making adjustments to the GDPR regulation. The analysis was conducted on the basis of the specific character of assets, the frequency and uncertainty of transactions being an element of the management of medical data.

The further part of the paper presents the essence of an institution and transactional costs in the perspective of the economics of transactional costs. The third part of the paper presents the most important GDPR regulations regarding the management of medical data. The fourth part includes the analysis of the impact of GDPR on the level of transactional costs in the management of medical data from the perspective of the specific character of assets, uncertainty and frequency of transactions. The conclusion includes the findings of the conducted analysis.

\section{The essence of transactional costs and the determinants of their level}

The economics of transactional costs is the main trend of New Institutional Economics (NIE). Research on the factors specifying the level of transactional costs is conducted using two basic trends of NIE [Gancarczyk, 2004]. In general, in NIE there are two isolated research areas and two types of institutions are discussed here [Williamson, 1998, 2000; Mènard, Shirley, 2005; Gancarczyk, 2005]. The first area regards the institutions of coordination (governance structures, institutions of governance) and institutions supervising contracts. Coordination institutions, which are discussed in the economics of transactional costs, are understood as the ways of regulating economic exchange that may be conducted by a company, market and indirect structures (hybrids) such as a formal long-term contract, a relation contract, or a joint venture. They largely influence the effectiveness of the functioning of economic entities. Both the supervision and incentives for the effectiveness in the realization of contracts serve as the point of reference for the theory of agencies. Another sphere of research is the institutional environment, i.e. mostly formal legislative regulations that have an impact on the level of transactional costs. This sphere is considered in the theory of the ownership right and the theory of public choice.

The principles specifying the effectiveness of the functioning of management entities are based on the economics of transactional costs and on the concept of institutions that determine the value of transactional costs accompanying the transactions. In general perspective, institutions denote sets of formal principles and informal principles, rules, orders, bans and procedures that have impact on the behavior of people and organize their activity [North, 1991; Gancarczyk, 2002; Gruszewska 2012]. In broader perspective, institutions refer to all norms, including the legislative and usual ones, as well as other game rules, and also create the 
possibility of making changes with regards to the needs of the contract parties [Fedorowicz 2004]. They may either complement or contradict one another. Institutions define the incentive structure of societies and economies in particular [North, 1994]. Institutions create certain patterns and standards of behaviour, thanks to which they reduce the uncertainty. They become the pattern of human interactions [North, 1990]. Additionally, they constitute the instrument used by individuals to maximize benefits, enhance prosperity, and reduce the transactional costs.

Institutional restrictions ban certain activities or impose certain conditions that must be met in order to initiate certain activities. Institutions may be imposed from the top down in the form of specific legislation or may be the effect of spontaneously created principles [Kuder, 2011]. Institutions exert a fundamental impact on economic activity (institutions matter) [Gruszewska, 2013]. They may be divided into formal and informal institutions. Formal institutions specify, among others, the legislative norms that regulate the political, economic, and social relations in which the economic entity is functioning. In another aspect, they may be divided into political relations that specify the system of authority, economic principles defining ownership rights, and contracts that specify the principles of particular contracts enabling exchange [North, 1990]. Informal institutions specify moral norms, customs, mentality, religious beliefs normalizing social interactions and reducing uncertainty in the relations between people. They stem from the cultural heritage shaped over a long time period [Kiełczewski, 2010]. The main subject of interest of NIE concerns mainly institutions of a formal character [Gorynia, 1999; Fiedor, 2013]. They change more quickly and their impact on the functioning of economic entities is more noticeable over a short time period.

Transactional costs are the main subject of research of the economics of transactional costs which is a trend of the New Institutional Economics. They are related to each exchange and occur as the effect of certain 'resistance' that results from the imperfection of a certain way of regulating economic exchange. It is manifested mainly in the limited rationality of economic entities, information asymmetry of the parties participating in the exchange, the changeable impact of the institutional surroundings, the way public entities function, as well as in the activity of monopolies. An information advantage of one of the parties of the contract increases uncertainty, which results in an opportunistic way of acting among the other parties of the contract. As a consequence, additional costs related to securing and monitoring the contract are created.

Transactional costs are defined in a variety of ways in scientific papers. The most frequently used aspects define these costs as [Gancarczyk, 2010]:

- Costs related to negotiations and signing transactions on the market [Coase, 1937];

- Costs that are created during the exchange of the ownership rights into assets and during the enforcement of rights to the exclusiveness of using these assets [Eggertsson, 1990];

- Costs that result from taking over, handing over and protecting ownership rights [Barzel, 1997]; 
- $\quad$ Costs resulting from the functioning of the economic system [Arrow, 1974];

- Costs created while using resources that are necessary for the exchange of ownership rights by the market [Kasper, Streit, 1998; Kasper, Streit, Boettke, 2012].

In one of the contemporary classifications, transactional costs are divided into three groups depending on where they stem from. They include [J. GodłówLegiędź, 2009; Małysz, 2003; Chotkowski, 2010]:

- Market transactional costs resulting from the mechanism of cooperation based on competition. These costs are related to seeking and collecting information (clearing the way for a contract), negotiating and making decisions concerning the signing of a contract, the costs related to the supervision of appointments, the quality and amount of products, and the costs of exacting rights and resolutions of the agreement;

- Transactional costs inside the company (costs of hierarchical organization). They include both the company's fixed and changeable costs;

- Public (political) transactional costs. These are the costs of organizing, maintaining, and modernizing the public order of a certain political, social, and economic system.

A similar contemporary perspective on transactional costs divides them into the costs resulting from [Gancarczyk, 2006]:

- The adjustment to public institutions regulating the functioning of the entities;

- The functioning of the entity in a certain structure generating a proper level of costs;

- Market exchange or partial market exchange.

In this paper transactional costs are considered as the costs of the adjustment to certain institutional requirements, both in a certain hierarchical structure and in either complete or only partly complete market exchange.

Transactional costs may be practically differentiated by dividing them into $e x$ ante costs that are created before the contract is signed and ex post costs created during its realization [Williamson, 1998]. Transactional costs of the transactions conducted directly on the market are the result of the spontaneous mechanism of cooperation based on competition [Legiędź, 2009]. Transactional costs regard, among others, the costs of coordinating the transaction. They include the costs of getting close to the contract's parties, setting the price which is the resultant of other criteria expected by the parties and of signing the contract. The conditions, which are shaped in a conventional way, are not perfect in terms of measuring the transaction results, changing its range, the withdrawal of parties from the transaction, the arrangement of mutual responsibility [Gruszecki, 2002]. This state leads to the necessity to increase additional transaction costs ex-post in order to specify in detail the conditions of realizing the contract. Owing to the imperfection of contracts, parties also incur the costs of lost benefits. In the case of complex transactions and high likelihood of opportunistic behaviors the aforementioned transactional costs are supplemented by the costs of monitoring and exacting agreements. They are larger 
when there is a considerable difference between the actual evaluation of the transaction and the contents of the contract signed [Gruszecki, 2002].Contracts are not fully unequivocal for the parties. They are frequently perceived in various ways. Additionally, they are not complete. In practice, each party leaves a proper margin for implementing changes according to the expected future usefulness of the contract, which brings additional transactional costs.

The basic forms of signing contracts include the market, vertical integration or indirect forms such as long-term contracts, regulations and public office [Williamson 1999]. Each of these forms has influence on the level of transactional costs. In the case of the optimal adjustment of forms to the existing institutional surrounding relatively low transactional costs may be incurred [Gancarczyk, 2010]. If the form of market coordination does not guarantee (to a satisfactory degree) the realization of the contract's bequests for the parties (while its maintenance causes considerably higher transactional costs), the more effective solution becomes the vertical integration of assets with one management (hierarchical structure). Additionally, it is assumed that, depending on the type and degree of the transaction complexity, the optimal solution would be mixed and hybrid solutions in the form of relation contracts.

The value of transactional costs incurred by the entity in a certain form of a contract is dependent on the specific character of assets, and on the frequency and uncertainty of management that takes place at the same time [Williamson, 1998]. Specific assets are understood as the investments for the needs of a certain exchange placed in resources and skills that lose their value in the situation of alternative use. Depending on the degree of complexity and advancement of the used technology, the entity's assets (in comparison with other solutions) become either less or more specific, which has an impact on the change of values of the interrelated transactional costs. In principle, the more complex the processes are, the higher qualifications of employees are required, which causes the increase of transactional costs. The more specific the assets, the more reduced the way of using them is.

Frequency is defined as the number of transactions made in a certain time unit [Williamson, 1991]. The parameter may be analyzed by making the distinction between typical transactions (repeatable) and non-typical (unrepeatable) transactions [Gruszecki, 2002]. Higher frequency results in the increase of transactional costs. The lack of equality between the contracting parties in terms of the access to information and the use of the acquired information advantage contributes to the fact that the choices are not made in an entirely rational way, the price is the only criterion of making transactions, whereas the entities make decisions in conditions of considerable uncertainty.

The uncertainty connected with management is of both natural origin that results from the unpredictability of the surroundings, and of behavioral origin that is related to limited rationality and opportunism [Gancarczyk, 2010]. The uncertainty of preserving the security of the contracting parties as the result of evading obligations, the reduced possibility of acting or any other symptoms of opportunistic behavior cause additional transactional costs for the participants of the exchange. 
The aforementioned deliberations result in the conclusion that the level of costs connected with certain transactions is influenced by the following basic factors [Gancarczyk, 2005, 2010; Pańkowska, 1995]:

- Institutional solutions proper for the surroundings in which the entity functions;

- Transaction properties;

- The asymmetry of information which means that information regarding a specific transaction is distributed in an asymmetrical way between the partners of the exchange;

- Limited access to information;

- Properties of entities, including their level of knowledge, abilities and motivation [Williamson, 1976];

- The specific character of using assets in the realization of certain transactions. They include the complexity, frequency, and uncertainty of a transaction [Williamson, 2000];

- Contracting forms that include market coordination, internal coordination (management entity), or mixed coordination (relation contracts).

The analysis of the impact of institutions on transactional costs is the major subject of research in the domain of the economics of transactional costs. The form of contracting as a choice usually ex post in relation to institutional solutions of the surroundings determines the specific level of transactional costs to a large degree. Its choice ought to be the effect of detailed analysis of the type of a certain transaction as well as of the specific character of assets used for realizing the assets [Gancarczyk, 2005]. Transactional costs are not measured directly, but constitute a theoretical point of reference, the referential category. Direct measurement concerns the determinants of transactional costs. Their impact on the level of transactional costs is tested [Masten, 1991]. Another method of measurement is the comparative analysis of transactional costs of certain transactions of certain characteristics taking place in certain institutional surroundings [Benham, 2000].

\section{Changes in the management of medical data in medical entities in view of the regulation of the European Parliament and the Council}

The bequests of the act on medical activity ${ }^{4}$ specify the following medical entities (art. 2 act 1 pt. 9 and art. 12 act 1):

- Hospitals;

- Medical care centres;

- Nursing homes;

- Therapeutic rehabilitation centres;

4 Act on medical activity of 15 April 2011 (uniform text.: Journal of Acts of 2018. item 160 with alterations). 


\section{- Hospices.}

Medical activity may be used as economic activity, for public use, charity and protection as well as for scientific and research purposes [Wołoszyn-Cichocka 2015]. Medical data processed in medical entities constitute a special category of personal data that needs to be protected to a larger degree. The basic regulations regulating the protection of data regarding patients in the national legislative order include the act on the protection of personal data ${ }^{5}$ and the act on patients' rights and the Commissioner for Patients' Rights ${ }^{6}$. The amendments to these acts were introduced in terms of their conformity with the GDPR regulation. In accordance with them, medical data ought to be processed for health-related purposes only when it is necessary for the specific person's data, necessary for the management of health care services and systems, as well as for social security [motive 53 of GDPR]. The management of medical data in medical entities is regulated by the following principles of usefulness [Krówczyński, 2017]:

- The accessibility of data, i.e. ensuring access to it whenever it is necessary;

- The completeness of data, i.e. ensuring adequate data so that a doctor or authorized medical personnel may make decisions, i.e. it is sufficient but at the same time it does not exceed the range that is necessary for the decision;

- The confidential character of the processed data, which means its protection from unauthorized use, leak for commercial purposes and from its use inconsistent with the interests of the patient;

- Ensured integral character of data in various systems, which enables their unequivocal presentation for the needs of the study, diagnosis, the selection of therapy and specification of the possibilities of financing it;

- Ensured accountability of data, i.e. the possibility of clear identification of a person that processes certain medical data.

The aforementioned rules aim at achieving the required standard as regards the management of medical data by a medical entity - while preserving the doctorpatient confidentiality and respect for the patient's dignity. These principles have formal character and aim at increasing the predictability of achieving the required usefulness in the management of medical data. The required usefulness increases simultaneously with the advancement of information technologies which create new possibilities for processing data both in terms of their type and purpose. The usability principles are the criteria for selecting adjustment activities to the new GDPR regulations. The new regulation of the European Parliament and the Council (GDPR) follows the changes taking place in the management of medical data. These changes are enforced by the development of information technologies that create

5 Act on the protection of personal data of 29 August 1997 (uniform text: Journal of Acts of 2016, item. 992 with alterations).

6 Act on patients' rights and the Commissioner for Patients' Rights of 6 November 2008 (uniform text: Journal of Acts of 2017, item 1318 with alterations). 
unprecedented possibilities of interfering with the privacy of persons whose data is used. New institutions aim at the reinforcement of the rights of physical persons whose data is processed by expanding the catalogue of data regarding the state of health. The concept of personal data regarding the state of health is specified in art. 4 of the GDPR regulation. In accordance with it, the data on the state of health includes personal data on the physical or mental health of a person, including the use of health care services that disclose information regarding the state of the person's health. The data discloses information on the past, present and future state of physical or mental health of a certain person. The data includes the information collected during the registration of this person for the health care services or during the provision of these services.

The data regarding the state of health, especially protected data, includes also genetic and biometrical data. Genetic data was specified in art. 4 of the GDPR regulation as personal data concerning either inherited or acquired genetic properties of a physical person that provides unique information that regards the physiology or health of this person and results mainly from the analysis of a biological sample from the particular physical person whose data is used. Biometrical data denotes personal data that results from special technical processing; regards physical, physiological or behavioral properties of a physical person; and either enables or confirms the unequivocal identification of that person, such as a face image or dactyloscopic data (art.4 GDPR). The inclusion of genetic and biometrical data into the special category of data was dictated by the development of information technologies processing data on the state of health in another, more expanded way.

The new regulation that obliges the administrator to use the risk based approach (art. 32 GDPR) exacts new activities related to the identification of the risk related to its estimation and to certain conduct in this aspect. In accordance with the new GDPR regulation, both the utility and system software must take into consideration data protection in the stage of designing (privacy by design) and the implicit data protection (privacy by default) (art. 32 GDPR). These principles also regard the software that is useful for the management of a medical entity. The software includes CRM systems that assist in the management of relations with patients, suppliers and other contractors (Customer Relationship Management). They include data regarding potential and present patients in order to achieve automation of processes in the relations between a medical entity and a patient. These solutions collect personal identification data of patients and suppliers as well as medical data, the history of contacts and fulfilled medical services, relations and links with other contractors, the conditions and the history of payments [Wrycza, 2010]. These processes are supported by the systems of electronic circulation of documents that are useful for contracting and accounting for medical provisions with the National Health Fund and other taxpayers. These systems control the distribution of work and documents and also reduce the manual activities that are replaced by the automatic processing of personal data, including medical data. In order to meet these requirements of GDPR, it is necessary to conduct detailed analysis of utility software, including office software (word processing programs and spreadsheet programs), specialist 
programs and databases. It is also required to analyze in detail the procedures for providing patients with medical documents, authorized persons and organs having authorization.

Security of data transmission may be ensured by using the SSL protocol (Secure Socket Layer). This protocol operates below the level of http protocol and ensures encrypted (confidential) data transmission [Pałka, 2013]. The security of transmission regards also internal security procedures used for sending data, including discs storing the processed data. The solution to it may be encrypting by using the mechanisms built into the operational system or software of external companies [Chudzikiewicz, 2010].

The GDPR regulation in art. 32 introduces new duties and responsibilities of the appointed data protection officer:

- Informing the administrator and persons responsible for processing personal data on their responsibilities connected with meeting the requirements related to the usefulness of management;

- Presenting (to the administrator and persons responsible for processing data) adequate recommendations regarding the evaluation of effects for data protection and monitoring the performance of it;

- Cooperation with the supervisory organ;

- Performing the function of the contact point for the supervisory organ and persons whose data is processed as regards issues related to the performed activity.

The function performed by the data protection officer as the contact point requires elaboration and implementation of proper procedures and cooperation with interested parties, including especially persons whose data is processed, and cooperation with the supervisory organ. Information regarding the processed personal data, disclosure or offering it to a person whose data is concerned or to an authorized person in accordance with the GDPR regulation must be supplemented, among others, by the following information:

- Contact data of the data protection officer;

- Legal basis of processing;

- Period when personal data will be processed;

- Information regarding the right to lodge a complaint to the supervisory organ;

- Information on automatic decision-making, including profiling;

- Informing the administrator and persons involved in the processing of personal data of their obligations related to meeting the requirements regarding the usefulness of management.

Therefore, it is necessary to supplement the contents of the present clauses with new bequests and divide them in terms of the purpose and range of data processing.

The new principles of entrusting personal data, which were specified in art. 28 of GDPR, oblige the administrator to use only the services of those entities that process entrusted personal data and guarantee the implementation of appropriate technical and organizational measures protecting the rights of persons whose data is used. The entity processing data must not use the services of another entity 
processing data unless it received either general or written approval of the administrator beforehand. If such approval was granted, the entity processing data informs the administrator of all the intended changes regarding either adding or changing the processing entities, thus the administrator has the possibility to express any objection to such changes.

The GDPR regulation adopts a new mechanism for controlling the compatibility of regulations. An administrator must demonstrate the use of protection measures that are technically and organizationally proper in relation to the existing risks, the scale of which is assessed by the administrator. The proceedings of the controlling organ take place at one administrative level, while the imposed sanctions are efficient, proportional and dissuasive (art. 84 GDPR). The penalties were specified in art. 83 of the regulation. In accordance with it, two amounts of penalties are adopted, depending on the type of offence:

- Less than $10 \mathrm{mln}$ Euro, whereas in the case of a company less than $2 \%$ of its total annual turnover from the previous turnover year;

- Less than $20 \mathrm{mln}$ Euro, whereas in the case of a company less than $4 \%$ of its total annual turnover from the previous turnover year.

The aforementioned deliberations point at the following, most important determinants of institutional changes included in the new GDPR regulation:

- The use of the risk-based approach (risk management: identification, evaluation, conduct);

- Default privacy settings;

- Secure transmission of medical data;

- The assignment of the Data Protection Officer;

- Ban on further assignment of processing medical data without the approval of the administrator;

- The expansion of the information obligation towards persons whose data is used;

- New mechanism for the control of compatibility with the GDPR regulation and sanctions in case of the violation of the decree bequests.

The aforementioned determinants have considerable influence on the usefulness of the management of medical data in medical entities and constitute the subject of analysis of the level of transactional costs.

\section{The impact of the most important institutional changes included in GDPR on the level of transactional costs in the management of medical data in medical entities}

The analysis regards the impact of the most important institutional changes included in GDPR on the activities related to the management of medical data in medical entities. The main activities in the management of medical data include [Krówczyński, 2017]: 
1 The maintenance and development of technical infrastructure for the processing and protection of personal data (including information infrastructure and software);

2 Creation, updating and realization of processes and procedures as well as the development of formal legislative and organizational principles of data management (elaboration of rule books and procedures, the arrangement of organizational hierarchy, the structure of the supervision of the way medical data is processed),

The analysis of the influence of the most important institutional changes comprised in GDPR on the activities related to the management of medical data results in the evaluation of the level of transactional costs in the aspect of the properties of the assets used for the realization of certain transactions (specific character of assets, frequency, and uncertainty) [Williamson, 2000]. Depending on the properties of the transactions, the adjustment activities for new regulations cause a certain change in the level of transactional costs.

The further part of the paper analyzes the influence of the most important institutional changes on the level of transactional costs in the aspect of the attributes of certain transactions (specific character of assets, frequency, uncertainty).

\subsection{Transactional costs of IT solutions for the protection of the processed medical data}

New GDPR regulations require the usage of more specific IT solutions for secure processing of medical data. These solutions include operational and service servers, application software, hardware, computer network, data storage devices, telecommunication and auxiliary devices [Wrycza, 2010]. Due to this fact, the frequency of inspections of this aspect will increase owing to the necessity of adjustment activities. They will be conducted not only ex post with the recommendation to apply appropriate corrective activities, but also ex ante in case of prepared implementations. This will considerably increase the amount of the transactional costs related to these transactions. Default privacy setting in the systems processing electronic medical data will reduce the uncertainty of incidents posing a hazard to confidentiality. The specific character of assets will increase owing to the diversity of applied programs and functional solutions used there. The frequency of transactions will increase as well, as regards designing new software and interrelated implementation procedures. There will be higher transactional costs of negotiating the conditions of contracts and their realization with the companies providing IT services.

Similar cost relations regard the implementation of the principles of secure information transmission. There will be less uncertainty as regards the risk related to the loss of data, whereas the specific character of assets will increase owing to the use of cryptographic devices. The frequency of operations will not change. New tasks and responsibilities of the appointed data protection inspector ought to reduce the uncertainty related to the management of medical data. On the other hand, the criteria of appointing the inspector are not specified in detail in the regulation and leave a large margin for free interpretation of regulations. Such a state of affairs 
increases the uncertainty of the way of interpreting the bequests of the GDPR regulation. Assets will become more specific and the frequency of transactions will increase, mainly owing to the increased accessibility of the personal data officer. Moreover, the rights of persons whose data is processed will be enhanced. As a consequence, the transactional costs will increase. The expansion of the information obligation in relation to persons whose data is used as well as the expansion of control mechanisms will increase the specific character of the assets and the frequency of transactions.

TABLE 1.

\section{Influence of the most important institutional changes of GDPR on the level of transactional costs of IT solutions}

\begin{tabular}{|c|c|c|c|c|}
\hline \multirow[b]{2}{*}{ lp. } & \multirow{2}{*}{$\begin{array}{c}\text { Type of the institutional } \\
\text { change }\end{array}$} & \multicolumn{3}{|c|}{ Transaction properties } \\
\hline & & $\begin{array}{l}\text { Specific character } \\
\text { of assets }\end{array}$ & Frequency & Uncertainty \\
\hline 1. & Risk based approach & + & + & - \\
\hline 2. & Default privacy setting & + & 0 & - \\
\hline 3. & Secure information transmission & + & 0 & - \\
\hline 4. & $\begin{array}{l}\text { Tasks and responsibilities of the } \\
\text { Personal Data Officer }\end{array}$ & + & + & + \\
\hline 5. & $\begin{array}{l}\text { Information obligation towards } \\
\text { persons whose data is used }\end{array}$ & + & + & - \\
\hline 6. & $\begin{array}{l}\text { Principles of assigning data } \\
\text { processing }\end{array}$ & + & 0 & - \\
\hline 7. & $\begin{array}{l}\text { Mechanism of controlling } \\
\text { compatibility and sanctions }\end{array}$ & + & + & + \\
\hline
\end{tabular}

Description: „,"-increase; „,-" decrease; „," - parameter without any change

Source: Author's own elaboration.

The implementation of the new principles of entrusting personal data results in the necessity to expand the functionality of software designed for these purposes. This will cause increase of the specific character of the assets. The frequency of transactions will not change significantly. The uncertainty related to transactions will be reduced owing to the additional functionality of the system that will ensure the integrity of data processed within the frameworks of the entrustment agreements.

The conducted juxtaposition of the influence of changes adjusting IT solutions to the GDPR regulation implies that in the case of each institutional change assets become more specific. Increased specific character of assets is accompanied by the increase of transactional costs. The frequency of transactions does not change. The uncertainty of management is reduced as the new regulations specify the range of authorizations and responsibility in the aspect of new technologies of processing medical data in a more detailed way. The level of transactional costs in the stage of 
implementing regulations increases considerably, mainly owing to the complexity of transactions that require more specialist forms of automatic processing of medical data. The increase of uncertainty regards imprecise rules of appointing the data protection officer. Increased uncertainty regarding the control of compatibility of data management with the GDPR regulation may be caused by the authorities of the supervisory board in terms of imposing financial penalties for the observed incorrectness and lack of precise units for measuring their value in case of certain violations.

\subsection{Transactional costs of creating and updating processes and procedures for protecting the processed medical data}

The development of formal legislative and organizational principles for the management of medical data, in the aspect of the most important institutional changes included in GDPR, forces medical entities to update the processes and verify most procedures and regulations. It needs to be done while taking into consideration the state of present technical knowledge, the costs of implementation, as well as the context, character, range and purposes of processing. In each case, the update requires an evaluation of the risk of violating the rights or the freedom of persons whose data is processed. The evaluation must be based on the criterion of the probability of the occurrence of potential risks and their potential effects. Owing to this, the assets will be more specific and the level of transactional costs will increase. More uncertainty regarding transactions will also be observed owing to the lack of previous experiences in this aspect. The present legal regulations did not require a risk-based approach during the checking. Default privacy settings and secure data transmission create the obligation to expand the bequests in the procedures related to designing systems and software for data processing. The assets in this aspect will become more specific. The frequency of transactions will not undergo considerable changes. However, the uncertainty related to transactions will be reduced because more restrictive protection procedures and default settings that secure medical data being used and encryption of their flow will reduce the risk of losing privacy. Ultimately, the level of transactional costs will increase. The appointment of a personal data protection officer will increase the specific character of assets and the frequency of transactions. It is influenced, among others, by the new obligations related to keeping records of the susceptibility to risk, estimating the potential risk of threats, and further proceedings in this aspect. There will be greater uncertainty connected with transactions owing to the imprecise principles of appointing the personal data inspector.

The extension of the information obligation towards persons whose data is processed (including the employees of the medical entity) causes greater transparency of the rights and obligations of the contract's parties. However, there will be greater uncertainty as regards providing information on the incidents that took place. After an incident when there is a high risk of undesired activities aimed at a person whose data is concerned, it is necessary to inform that person of the potential consequences of the incident and corrective activities undertaken by the 
medical entity. Such information must be forwarded to the supervisory board in a certain manner. The lack of precise regulations related to the way of assessing the degree of risk and referring it to the required scale of security creates considerable uncertainty of data management in the aspect of both the processes and procedures. The specific character of activities in this aspect will increase accordingly to the range and way of processing medical data. The consequence of it will be the increase of transactional costs.

New principles of entrusting the processing of personal data will cause greater complexity of agreements between the entities in terms of both creating standards of processing data and each case of expressing approval by the administrator for the entrusting of processed data by other entities. The frequency of transactions in this domain will increase owing to the obligation to inform entities of the observed changes each time they take place. The uncertainty accompanying the transactions ought to be reduced in terms of the awareness of both the rights and obligations of the entities processing data in the form of entrusting.

New financial sanctions specified in the GDPR regulation increase the uncertainty of management, owing to the specification of only very restrictive upper limits of financial penalties. The specific character of assets and the frequency of transactions will grow, which will increase the transactional costs of supervision and control.

TABLE 2.

\begin{abstract}
Influence of the most important institutional changes of GDPR on the level of transactional costs of creating and updating processes and procedures for protecting the processed medical data
\end{abstract}

\begin{tabular}{|l|l|c|c|c|}
\hline \multirow{2}{*}{ No. } & \multirow{2}{*}{ Type of institutional change } & \multicolumn{2}{|c|}{ Transaction properties } \\
\cline { 3 - 5 } & & $\begin{array}{c}\text { Specific character } \\
\text { of assets }\end{array}$ & Frequency & Uncertainty \\
\hline 1. & Risk based approach & + & + & + \\
\hline 2. & Default privacy setting & + & 0 & - \\
\hline 3. & Secure information transmission & + & + & - \\
\hline 4. & $\begin{array}{l}\text { Tasks and responsibility of the } \\
\text { Data Protection Officer }\end{array}$ & + & + & + \\
\hline 5. & $\begin{array}{l}\text { Information obligations towards } \\
\text { persons whose data is used }\end{array}$ & + & + & - \\
\hline 6. & $\begin{array}{l}\text { Principles of entrusting data } \\
\text { processing }\end{array}$ & + & + & + \\
\hline 7. & $\begin{array}{l}\text { Controlling compatibility and } \\
\text { sanctions }\end{array}$ & + & + & + \\
\hline
\end{tabular}

Description: "+" - increase; “-” decrease; "0" - parameter without any change

Source: own elaboration. 
As in the case of IT solutions, the main factor in the increase of transactional costs of adjusting processes and procedures is the specific character of assets. Lower frequency of transactions or reduced uncertainty related to transactions are not observed. The uncertainty of using the risk based approach increases, which may be explained by the fact that the hitherto used principles for inspecting processes and procedures were more static and, most frequently, they were not based on estimating the risk. The general level of transactional costs of implementation increases, similarly as in the previous case.

\section{Conclusion}

New regulations specified by the GDPR regulation are likely to have a considerable impact on the increase of transactional costs of adjustment activities in terms of IT solutions as well as in terms of both processes and procedures of the management of medical data. The participation of particular parameters of changes is going to have a diverse impact on the level of transactional costs. It depends on a certain baseline of IT solutions as well as processes and procedures of data protection which initiate the introduction of changes. Those medical entities that are more advanced in the automatic processing of medical data are in general capable of adjusting to new institutional changes with fever resources. The analysis implies that greater complexity of assets is accompanied by higher frequency of transactions, which, in turn, causes the increase of transaction costs. The implementation of new GDPR regulations in the management of medical data will increase the specific character of assets and their frequency, which, in turn, will cause an increase of transactional costs.

The increase of the transactional costs related to seeking certain partners on the market, in particular in the sphere of the improvement of IT solutions, including the preparation, negotiation, and monitoring of contracts (especially in terms of entrusting data), as well as collection of information necessary for signing contracts in the situation where contractors change will be observed. New obligations related to information will change the procedures and processes taking place during the circulation of information. The approach based on risk enforces a more specific character of all the assets and consequently will result in the increase of transactional costs. Savings in transactional costs considered over longer time periods simultaneously with the maintenance or the increased usefulness of the management of medical data in medical entities are dependent on their proper estimation ex ante and on the implementation of new solutions ex post with reference to the optimal form of coordinating activities.

\section{References}

Aldridge A. E., 2006, Rynek, Sic, Warszawa. Arrow K. J., 1974, The limits of organization, Norton, New York. 
Barta J., Fajgielski P., Markiewicz R., 2015, Ochrona danych osobowych: komentarz, Wolters Kluwer, Warszawa.

Barta, P., Litwiński P., 2015, Ustawa o ochronie danych osobowych, Wydawnictwo C.H. Beck, Warszawa.

Banyś T., Luczak J., 2014, Ochrona danych osobowych w praktyce, Prescom, Wrocław.

Barzel Y., 1997, Economic analysis of property rights, Cambridge University Press, Cambridge.

Benham, A., Benham L., 2000, Measuring the costs of exchange. C. Ménard, (Ed.), Institutions, contracts and organisations, Edward Elgar Publishing, Cheltenham.

Chojnacki M., Gastecka A., 2014, Informatyzacja opieki zdrowotnej w Polsce jako kierunek poprawy efektywności kosztowej systemu, „Progress in Economic Sciences”, nr 1.

Chotkowski J., 2010, Instytucje rynkowe i koszty transakecyjne-kluczowe pojecia nowej ekonomii instytucjonalnej, „Roczniki Nauk Rolniczych”, nr 97.

Chudzikiewicz J., 2010, Programowe zabezpieczenie plików przechowywanych na dyskach zewnetrznych, „Biuletyn Instytutu Automatyki i Robotyki”, nr 16.

Coase R. H., 1937, The nature of the firm, "Economica, New Series", nr 4(16).

David R., Han S-K., 2004, A systematic assessment of the empirical support for transaction cost economics, "Strategic Management Journal", nr 1.

Fiedor B., 2010, Kryzys gospodarczy a kryzys ekonomii jako nauki, „Ekonomista”, nr 4.

Eggertson T., 1990, Economic behavior and institutions, Cambridge University Press, Cambridge.

Gancarczyk M., 2002, Instytucja a organizacja w nowej ekonomii instytucjonalnej, „Gospodarka Narodowa", nr 5-6.

Gancarczyk M., 2006, Koszty transakcyjne - teoria i sposób pomiaru, „Ekonomika i Organizacja Przedsiębiorstwa", nr 6.

Gancarczyk M., 2010, Oportunizm w relacjach przedsiębiorstw wedtug O.E. Williamsona, „Ekonomika i Organizacja Przedsiębiorstwa”, nr 1.

Gancarczyk M., 2015, Proces wrrostu przedsiębiorstwa w swietle podejścia zasobowego i teorii kosztów transakcyjnych, „Gospodarka Narodowa”, nr 5.

Gorynia M., 1999, Przedsiebiorstwo w nowej ekonomii instytucjonalnej, „Ekonomista”, nr 6.

Grego-Hoffmann M., 2013, Odpowiedzialność podmiotów leçniczych i personelu medycznego, Prescom, Wrocław.

Gruszecki T., 2002, Współczesne teorie przedsiębiorstwa, Wydawnictwo Naukowe PWN, Warszawa.

Gruszewska E., 2013, Instytucje a proces tworzenia kapitalu w Polsce, Wydawnictwo Uniwersytetu w Białymstoku, Białystok.

Hardt L., 2008, Rozwój ekonomii kosztów transakcyjnych, od koncepcji do operacjonalizacji, Fundacja Promocji i Akredytacji Kierunków Ekonomicznych, Warszawa.

Informatyka ekonomiczna: podręrnik akademicki, 2010, S. Wrycza (red.), Polskie Wydawnictwo Ekonomiczne, Warszawa.

Jagielski M., 2010, Prawo do ochrony danych osobowych. Standardy europejskie, Wolters Kluwer, Warszawa.

Kasper W., Streit M. E., Boettke, P. J., 2012, Institutional economics: Property, competition, policies. Edward Elgar Publishing, Cheltenham. 
Kasper, W., Streit M. E., Manfred E., 1998, Institutional Economics, Edward Elgar Publishing, Cheltenham.

Kautsch M., Poznański D., 2009, Informatyzacja w zakładach opieki zdrowotnej. Wspótczesne ayzwania menedżerskie w ochronie zdrowia, Olsztyńska Wyższa Szkoła Informatyki i Zarządzania, Olsztyn

Kiełczewski D., 2010, Prawo jako instytucja, „Optimum. Studia Ekonomiczne”, nr 2(46)

Klein B., Crawford R. G., Alchian A. A., 1978, Vertical integration, appropriable rents, and the competitive contracting process, "The Journal of Law \& Economics", nr 2(21).

Klimczak B., 2006, Wybrane problemy i zastosowania ekonomii instytucjonalnej, Wydawnictwo Akademii Ekonomicznej im. Oskara Langego, Wrocław.

Krówczyński W., 2017, Wybór formy koordynacji (governance mode) dla gospodarowania danymi osobonymi pacjentów w podmiotach leczniczych. „Optimum. Studia Ekonomiczne”, nr 2(86).

Kuder D., 2011, Pojecie instytucii w teorii ekonomii. „Nierówności społeczne a wzrost Gospodarczy", nr 19.

Madhok A., 2002, Reassessing the fundamentals and beyond: Ronald Coase, the transaction cost and resource-based theories of the firm and the institutional structure of production, "Strategic Management Journal", nr 6.

Małysz J., 2003, Instytucje a kosaty transakcyjne w świetle neoinstytucjonalnej ekonomii. „Ekonomista”, nr 3.

Masten S. E., Meehan J. W., Jr., Snyder E. A., 1991, The costs of organization, "Journal of Law, Economics, and Organization", nr 1.

Menard C., Shirley M. M., 2005, Handbook of new institutional economics, Springer, Dordrecht.

Nojszewska E., 2011, System ochrony zdrowia w Polsce, Wolters Kluwer, Warszawa.

North D. C., 1984, Transaction Costs, Institutions, and Economic History, "Journal of Institutional and Theretical Economics", nr 140.

North D. C., 1990, Institutions, institutional change and economic performance, Cambridge University Press, Cambridge.

North D. C., 1991, Institutions, "Journal of Economic Perspectives", nr 5.

North D. C., 1994, Economic Performace Through Time, "American Economic Review". nr 84.

Nowakowski B., Jędruszczak A., Gałach A., 2013, Ochrona danych osobonych, informacii niejawnych $i$ systemón teleinformatycznych w sektorze publicznym, Wydawnictwo $\mathrm{CH}$ Beck, Warszawa.

Pańkowska M., 1995, Teoria kosżtón transakcyjnych wedtug Olivera Williamsona, Ruch Prawniczy, Ekonomiczny i Socjologiczny", nr 3.

Saryusz-Wolska H., Wronka M., 2013, Efeketywność w opiece zdrowotnej - zarys wielowymiarowego problemu w okresie transformacji, „Studia Ekonomiczne”, nr 168.

Suchecka J., 2010, Ekonomia ₹drowia i opieki ₹drowotnej, Wolters Kluwer, Warszawa.

Szymczyk D. M., Horoch A., 2013, Implementacja elektronicznej dokumentacji medycznej, cz. 1 Wptyw na efektywność pracy personelu medycznego, „Medycyna Ogólna i Nauki o Zdrowiu", nr 19.3. 
Williamson O. E., 1973, Markets and hierarchies: some elementary considerations, "The American Economic Review", nr 2(63).

Williamson O., 197,9 Transaction-cost economics: The governance of contractual relations, "Journal of Law and Economics", nr 2.

Williamson O. E., 1985, The economic institutions of capitalism, The Free Press, New York.

Williamson O. E., 1989, Transaction cost economics [in:] Handbook of industrial organization, R. Schmalensee, R. Willig (eds), vol. 1, Elsevier Science Publishers, Amsterdam.

Williamson O. E., 1991, Comparative economic organization: The analysis of discrete structural alternatives, "Administrative Science Quarterly", nr 2.

Williamson O. E., 1998, Transaction costs economics: How it works, where it is headed, "De Economist", nr 1.

Williamson O. E., 2000, The New Institutional Economics Taking Stock, Looking Abead, "Journal of Economic Literature" t. 38, nr 3.

Williamson O. E., 2005, The economics of governance, "The American Economic Review", nr 95.2.

Wołoszyn-Cichocka A., Lubeńczuk G., 2015, Džiałalnośc lecznicz̧a - pojecie oraz formy $i$ zasady wykonywania, „Studia Iuridica Lublinensia”, nr 23(65).

Wyka T., Nerka A., 2012, Ochrona danych osobowych podmiotów objetych prawem pracy i prawem ubezpieczeń spolecznych, Wolters Kluwer Polska, Warszawa.

Ząbkowicz A., 2003, Wspótczesna ekonomia instytucjonalna wobec głównego nurtu ekonomii, „Ekonomista”, nr 6.

Ząbkowicz A., 2006, Instytucje i wžrost gospodarki Japonii, Wydawnictwo Uniwersytetu Jagiellońskiego, Kraków. 